\title{
Towards a New Model for Implied Metaphor Translation: English Translations of Al Muallaqat
}

\author{
Aiman Sanad Al-Garrallah \\ Department of English, Al-Hussein Bin Talal University, Jordan \\ E-mail: Aiman-Sanad@hotmail.com
}

Doi:10.7575/aiac.alls.v.7n.3p.178

URL: http://dx.doi.org/10.7575/aiac.alls.v.7n.3p.178
Received: 17/01/2016

Accepted: 24/03/2016

\begin{abstract}
This two-part paper argues that metaphor in both English and Arabic is defined and classified in almost the same way with some slight, but far from insignificant, differences. Those differences along with the linguistic nature of implied metaphor can be attributed to the failure in translating that type of metaphor from Arabic into English as shown particularly in Jones', Johnson's, and Arberry's translations of Al Muallaqat. The fourteen examples of implied metaphor, chosen from "Muallaqa of Imru Al-Qais," are translated by employing two main strategies based on the linguistic component of implied metaphor - none of which (this study argues) succeeds in translating implied metaphor into implied metaphor. In criticizing some, if not all, prominent models suggested by eminent figures, this study argues that theorists since the 1980s have not been involved in proposing new procedures that settle down such a problem in lieu of being preoccupied with iterating almost what Newmark (1988) suggests. Accordingly, this paper suggests a new cross-linguistic classification of metaphor - a classification that might better belittle the discrepancies of other classifications. More importantly, this study proposes a new model for translating implied metaphor into implied metaphor.
\end{abstract}

Keywords: Metaphor, Isti Sarah, Implied Metaphor, Vehicle-oriented Metaphor, Tenor-oriented Metaphor, Pre-Islamic Poetry, Al Muallaqat, Super-ordinate Metaphor, Subordinate Metaphor

\section{Introduction}

Al Muallaqat can be considered the most famous landmarks of Arabic literature, composed before the advent of Islam by the greatest Pre-Islamic poets. Those Muallaqat almost similarly use a systematic structure. Each Muallaqa or qasidah begins with "weeping over ruins." Then it describes "the departure of tribes," "the erotic encounters," to use Decter's (2007, p. 43) words, the poet's desert adventures, the night, the horse, the camel, and the birds. In the main, the poet celebrates his generosity, bravery, and his mastery of his poetic language. Among the most remarkable Muallaqat is "Muallaqa of Imru Al-Qais." Imru Al-Qais bin Hujr al-Kindi (520 AD - 565 AD) was one of the most eminent PreIslamic poets, renowned for his metaphorical portrayal of the woman, the desert, the horse, the camel, the night, the storm, the wolf, to name but some, if not the most recurring, topoi. This metaphorical description is highly appreciated by Al-Jurjani (n.d.), Ibn Al-Mutaz (1981), Al-Khafaji (1982), among many other rhetoricians.

Some Western Orientalists translated Muallaqat into English. Among the most notable English translations are Jones' The Mo'allakat or Seven Arabian Poems (1807), Johnson's The Seven Poems Suspended in the Temple at Mecca (1893), and Arberry's The Seven Odes (1953). In collating the target and source texts, differences on semantic and syntactic levels come to the fore due to the linguistic subtleties between the two languages. More to the point, common to all those translations is the failure to translate implied metaphor - a failure manifested in these three translations of "Muallaqa of Imru Al-Qais" as a prime case in point. Therefore, the purpose of this two-part study is fourfold: first, it evaluates implied metaphor translation in Jones', Johnson's, and Arberry's translations of "Muallaqa of Imru Al-Qais." Second, it contrasts the concept and types of metaphor in English and Arabic. Third, it suggests a new metaphor classification, and finally it proposes a new model for implied metaphor translation.

\section{Literature Review}

Arabic translated poetry discourse represents a less explored field in the study of metaphor translation. Few studies, involved in the issue of metaphor in Arabic, can be counted on the fingers of one hand. Alhasan (2012) stylistically analyzes the Blunts' translation of Al Muallaqat in terms of semantics and syntax, but she leaves out of account metaphor translation. In his interesting paper on metaphor in modern Arabic poetry, Simawe (2001) argues that AlQais' Muallaqa includes only twenty-four examples of simile and six examples of metaphor. This is by no means an accurate account since some of the examples, considered as implied metaphor, are in fact examples of simile. The poem encompasses fourteen examples of implied metaphor, most of which have been left out of account by Simawe. Moreover, Simawe does not only refer to the translator of those lines, but he also does not even analyze the translation problems into the bargain. In his enthusiastic call for innovation, Abu Libdeh (2011) theoretically explains the outfits of Arabic figures of speech, surveying various definitions of these figures of speech by Western and Arab theorists. What 
is appealing in his paper is the ability to coin Isti Yarah as metaphor proper without justifying this ambiguous categorization. Drawing on her own experience, Rihani (2002) enumerates the problems she faces during translating Nizar Qabbani's "Granada;" however, she does not suggest any new model for metaphor translation from Arabic into English. Dickins, Hervey, and Higgins (2002) examine the problems of metaphor translation from Arabic into English. In modifying Newmark's typology (1988) and Lakoff and Johnson's model of metaphorical schemata (2003), they suggest two (to say confusing) models for metaphor translation from English into Arabic. Youssefi's (2009) An Analysis of the Translation of Metaphors in Hafiz's Selected Poems; Rura's "Analysis of Translated Tropes: Metaphors, Similes \& Analogies in a Case Study of the English \& Dutch Translations of the Russian Poet Alexander Galich" (2010); and Zohdi and Saeedi's Translating Metaphor and Simile from Persian to English: A Case Study of Khayyam's Quatrains (2011); these are the few studies that deal with metaphor translation into English.

\section{Methodology}

1- Material: The corpus of this study consists of the Arabic version of "Muallaqa of Imru Al-Qais" and its English translations by Jones, Johnson, and Arberry.

2- Procedures: After reading the Arabic version of "Muallaqa of Imru Al-Qais," fourteen examples of implied metaphor are found. English translations of those examples are identified in Jones', Johnson's, and Arberry's translations. Strategies used in translating those examples are identified and analyzed.

\subsection{Data Analysis}

It is found that Jones translated only twelve examples and ignored two, whereas each of Johnson and Arberry translated fourteen examples. Consider the following table:

Table 1. Strategies Employed in Implied Metaphor Translation

\begin{tabular}{|c|c|c|c|c|}
\hline \multicolumn{2}{|c|}{ Strategy } & \multicolumn{3}{|c|}{ Poets } \\
\hline & & Jones & Johnson & Arberry \\
\hline \multirow{9}{*}{$\begin{array}{l}1 . \\
\text { Translating } \\
\text { the explicit } \\
\text { linguistic } \\
\text { component } \\
\text { (i.e. tenor/ } \\
\text { vehicle) }\end{array}$} & $\begin{array}{l}\text { 1. Keeping the same } \\
\text { metaphor }\end{array}$ & $\begin{array}{l}\text { 1. nor withhold from me the } \\
\text { fruits of thy love, which again } \\
\text { and again may be tasted with }\end{array}$ & $\begin{array}{l}\text { 1. and do not repel me } \\
\text { from your repeatedly } \\
\text { tasted fruit* }\end{array}$ & $\begin{array}{l}\text { 1. and oh, don't drive me } \\
\text { away from your } \\
\text { refreshing fruit. }\end{array}$ \\
\hline & & & & $\begin{array}{l}\text { 2. She turns away, to } \\
\text { show a soft cheek, and } \\
\text { wards me off, with the } \\
\text { glance of a wild deer of } \\
\text { Wajra, a shy-gazelle with } \\
\text { its fawn. }\end{array}$ \\
\hline & & & & $\begin{array}{l}\text { 3. the cloud started } \\
\text { loosing its torrent about } \\
\text { Kutaifa }\end{array}$ \\
\hline & & & & $\begin{array}{l}\text { turning upon their beards } \\
\text { the boles of the tall } \\
\text { kanahbals. }\end{array}$ \\
\hline & 2. Using personification & 1. Other horses that swim & $\begin{array}{l}\text { 1. Then I said to him, } \\
\text { (i. e., the night), when } \\
\text { he stretched his loins* }\end{array}$ & $\begin{array}{l}\text { 1. and I said to the night, } \\
\text { when it stretched its lazy } \\
\text { loins }\end{array}$ \\
\hline & & & $\begin{array}{l}\text { 2. and followed it with } \\
\text { his buttocks* }\end{array}$ & $\begin{array}{l}2 \text {. followed by its fat } \\
\text { buttocks }\end{array}$ \\
\hline & & & $\begin{array}{l}\text { 3. and removed distant } \\
\text { his breast* }\end{array}$ & $\begin{array}{l}\text { 3. and heaved off its } \\
\text { heavy breasts . }\end{array}$ \\
\hline & 3. Using simile & $\begin{array}{l}\text { 1. she gave a timid glance with } \\
\text { languishing eyes, like those of a } \\
\text { roe in the groves of Wegera } \\
\text { looking tenderly at her young }\end{array}$ & $\begin{array}{l}\text { 1. She }[\ldots] \text { is } \\
\text { prohibiting me from } \\
\text { caressing her with a } \\
\text { glancing eye, like that } \\
\text { of a wild animal, with } \\
\text { young, in the desert of } \\
\text { Wajrah* }\end{array}$ & -- \\
\hline & $\begin{array}{l}\text { 4. Incorporating the } \\
\text { implicit component }\end{array}$ & $\begin{array}{l}\text { 1. nor withhold from me the } \\
\text { fruits of thy love, which again } \\
\text { and again may be tasted with } \\
\text { rapture. }\end{array}$ & $\begin{array}{l}\text { 1. your two eyes did } \\
\text { not flow with tears, } \\
\text { except to strike me } \\
\text { with your two arrows }\end{array}$ & $\begin{array}{l}\text { 1. Your eyes only shed } \\
\text { those tears so as to strike } \\
\text { and pierce with those two } \\
\text { shafts of theirs. }\end{array}$ \\
\hline
\end{tabular}


2. yet thy tears flow merely to wound my heart with the shafts of thine eyes.
5. Losing the metaphorical effect in my broken heart*

$--$

1. many a leather

water-bag of the people, I have placed its strap over my shoulder.

2.and he who cultivates after the manner of my cultivation and your cultivation will become thin.*
1. just draw off my garments from yours, and they will slip away of all sorts of folk I have slung by its strap over my shoulder.
2. Many's the water-skin

1. The storm

commenced pouring

out its waters over

Kathaifah overturning

upon their faces the

big trees called

kanahbul

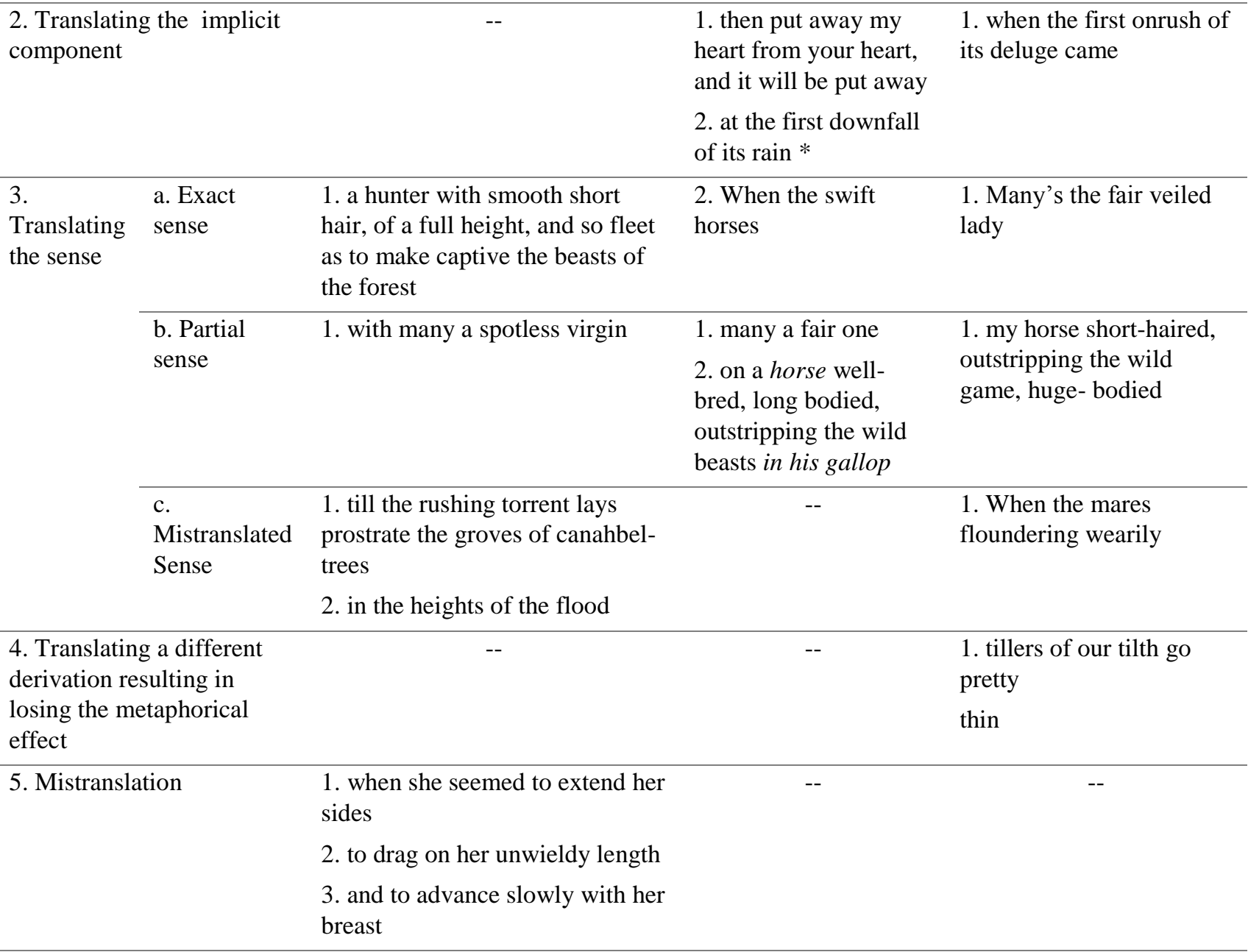

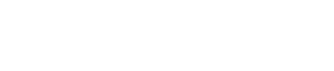

2. Translating the implicit component

\section{1. then put away my}

\section{When the swift} as to make captive the beasts of he forest

Mistranslated trees $\begin{array}{ll}\text { 2. Deleting } & 1 . \text { Translating a relevant } \\ \text { the explicit } & \text { word and keeping almost }\end{array}$

the explicit component (i.e. tenor/ vehicle)

1. Translating a relevant
word and keeping almost
the same metaphor

Table (1) shows the only two strategies used by Jones, Johnson, and Arberry in translating fourteen instances of implied metaphor chosen from "Muallaqa of Imru Al-Qais." Apparently those two strategies involve either translating or deleting the explicit linguistic component, which must be either the tenor or the vehicle. ${ }^{\mathrm{i}}$ In translating the explicit linguistic component, the translators kept the same metaphor, used personification and simile, incorporated the implicit component, and lost the metaphorical effect. Keeping the same metaphor and using personification, because of retaining almost the same metaphorical effect, are more effective than the other options. As regards keeping the same metaphor, Arberry translated only three examples, whereas each of Jones and Johnson translated only one example. Accordingly, Arberry's translation is more effective than the other two translations. Out of the fourteen examples, only one example, in which the translators kept the same metaphor, was similarly translated by the three translators. This transliterated 
instance, wa la tub Sideeni min janakil-mu Sallali, ${ }^{i i}$ was translated by Jones as "nor withhold from me the fruits of thy love, which again and again may be tasted with rapture;" by Johnson as "and do not repel me from your repeatedly tasted fruit;" and by Arberry as "and oh, don't drive me away from your refreshing fruit." In translating that example, the translators succeeded in keeping the same metaphor due to the fact that using the tree and fruits as symbols of love and sexuality is unsurprisingly common in both English and Arabic cultures.

In using personification, Jones translated iða mas-sabiћatu as "other horses that swim." Unlike Jones, Johnson used personification to translate fa qultu lahu lamma tamaTTa biSulbihi, wa ardafa a Sd Zazan, and wa na?a bikalkali, as "Then I said to him, (i. e., the night), when he stretched his loins," "and followed it with his buttocks" and "and removed distant his breast," respectively. In addition, Johnson, unlike Jones and Arberry, used glossing in order to make meanings clear as shown in Table (1) in the examples marked with an asterisk (*). Like Johnson, Arberry translated the same three examples as "and I said to the night, when it stretched its lazy loins," "followed by its fat buttocks," and "and heaved off its heavy breasts." Both Johnson and Arberry correctly identified the two main components of each example. In this transliterated example, fa qultu lahu lamma tamaTTa biSulbihi, the explicit component is biSulbihi, serving as the tenor, and meaning "camel's loins," whereas the implicit component is "the midnight," supposedly serving as the vehicle. Both translators retained the loins and assigned them to the midnight. In this way, the night is described as a camel and the midnight as its loins. Thus, stretching of the lions stands for the late approach of the midnight because of the lost love.

Jones and Johnson similarly used simile to translate only one example. Jones translated bi naĐiratin min wahSI wad Srata muTfili as "she gave a timid glance with languishing eyes, like those of a roe in the groves of Wegera looking tenderly at her young." However, Johnson translated the same example as "prohibiting me from caressing her with a glancing eye, like that of a wild animal, with young, in the desert of Wajrah."

Along with translating the explicit linguistic component, the translators incorporated the implicit component when translating the following example illa litaDribi bisahmaiki. Jones translated it as "yet thy tears flow merely to wound my heart with the shafts of thine eyes;" Johnson translated it as "your two eyes did not flow with tears, except to strike me with your two arrows in my broken heart;" and Arberry translated it as "Your eyes only shed those tears so as to strike and pierce with those two shafts of theirs." The three translators incorporated the implicit linguistic component (i.e. the tenor) which is the tears in lieu of bisahmaiki, which is the explicit component, meaning "your two arrows." This similitude among the three translators is attributed unsurprisingly to the association of love or tears with arrows in both cultures.

In two cases, Johnson's and Arberry's translations of the explicit linguistic component result in demetaphorizing two translated examples. The following example, wa qirbati aqwamin d 3a Saltu SiSamaha Sala kahilin minni, was translated by Johnson as "many a leather water-bag of the people, I have placed its strap over my shoulder," and by Arberry as "Many's the water-skin of all sorts of folk I have slung by its strap over my shoulder." In the source culture, qirbati, meaning "water-bag," is identified with the rights of people. Because this seems uncommon in the target culture, those translations demetaphorized that source verse in the target language.

As regards the second strategy, deleting the explicit linguistic component belittles the effectiveness of this strategy because it may result in losing the metaphorical essence or even in mistranslating the source text. Jones, Johnson, and Arberry employed this strategy seven times, six times, and five times, respectively. Instead, the three translators replaced the explicit linguistic component by translating only an exact, partial, mistranslated sense, or by translating the implicit component.

In one case, only Johnson translated a relevant word to the explicit linguistic component and kept the same metaphor. jakubbu Salal-aðqani dawhal-kanahbali, was translated as "The storm commenced pouring out its waters over Kathaifah overturning upon their faces the big trees called kanahbul." In the transliterated example, the explicit linguistic component is Salal-aðqani, meaning "chins." It was deleted and replaced by a relevant word, which is "faces." This replacement does not change the meaning of that metaphor, so the translators, in so doing, kept the same metaphor. Further, Johnson and Arberry translated the implicit linguistic component in lieu of the explicit linguistic component. In the following example, Saraneena wablihi, the explicit linguistic component is Saraneena, meaning "noses," the implicit component is "first downfall." Johnson translated it as "at the first downfall of its rain," whereas Arberry translated it as "when the first onrush of its deluge came." Both translators replaced Saraneena by "first downfall" and "first onrush." In both translations, metaphor is apparently lost.

With respect to translating the sense, it is noticed that the three translators employed this strategy to translate almost the same examples. Such a strategy is not effective because metaphor is lost, and the sense itself is not always complete. For instance, in wa baiDati xidrin, the explicit linguistic component is baiDati, meaning "egg," and the implicit linguistic component is "the beloved." In so doing, the beloved is described as virgin, pure, clean, and veiled. The three translators deleted the explicit linguistic component and translated the exact or partial sense. The same example was translated by Jones as "with many a spotless virgin," by Johnson as "many a fair," and by Arberry as "Many's the fair veiled lady." Jones and Johnson translated the partial sense, whereas Arberry translated the exact sense. No matter which sense they translated, they destroyed metaphor, so to speak.

As translating a different derivation along with the loss of metaphor, only Arberry employed it to translate wa man

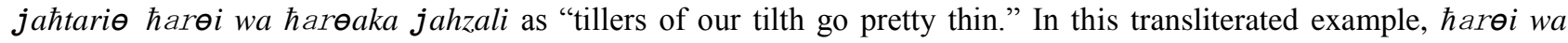




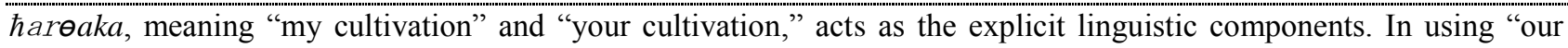
tilth," Arberry's translation has lost the metaphorical effect.

Out of the fourteen examples, Johnson and Arberry translated four and six examples respectively in which both used personification and kept the same metaphor. However, Jones translated only one example out of twelve in which he used only personification. Apparently, Jones' translation was the poorest, whereas Johnson's and Arberry's translations were quite equally more faithful than Jones'. This failure in translating implied metaphor from Arabic into English underlines the significance of English and Arabic definitions and classifications of metaphor, and the problems of the most well-known metaphor translation models.

\section{Definitions of Metaphor}

For the purpose of this study, it is significant to begin with various and cross-cultural definitions of metaphor. On a linguistic level, according to The Online Etymology Dictionary, the English word, metaphor, derives from "M.Fr. metaphore (O.Fr. metafore, 13c.), and directly from L. metaphora, from Gk. metaphora "a transfer," especially of the sense of one word to a different word, lit. "a carrying over," from metapherein "transfer, carry over; change, alter; to use a word in a strange sense," from meta- "over, across." In the same vein, Deignan (2005, p. 34) iterates, "metaphor is a word or expression that is used to talk about an entity or quality other than that referred to by its core, or most basic meaning. This non-core use expresses a perceived relationship with the core meaning of the word, and in many cases between two semantic fields." Aristotle (Cohen, 2003) explains the definition further by claiming that one thing is given the name of another, which do not resemble each other. In this sense, metaphor involves transferring one thing from one realm to another thing from a completely different realm. In supporting this, Aristotle (Stamvobsky, 1988, p. 117) argues, "[m]etaphor consists of giving the thing a name that belongs to something else; the transference being from genus to species, or from species to genus, or from species to species, or on grounds of analogy."

On a literary level, the meaning and attributes of one thing are transferred to another thing, resulting in its unusual, nonliteral meaning. In this sense, metaphor can be seen as a word semantically deviated from the linguistic, logical norms. In a similar way, Newmark (1988, p.105) views metaphor as "the figurative word used, which may be one-word, or "extended" over any stretch of language from a collocation to the whole text." It is in this sense that metaphor is considered as a figure of speech in which a word is semantically dislocated and alienated in that it becomes odd according to the norms of logic. Furthermore, metaphor refers to identifying two things, notions, objects, or names on the basis of analogy. It is a kind not only of identification but also of comparison. According to Vivian (1900, p. 109), it is "[a]similitude briefly expressed without any indication of comparison." More obviously, Aristotle (Stamvobsky, 1988, p. 12) defines it as "an elliptical simile, a comparison of things without the use of 'like' or 'as'." Accordingly, the sentence, "John is a lion," is an example of metaphor, whereas "John is like a lion" is an example of simile. According to Dickins et al (2002, p. 147), "[m] etaphor can be defined as a figure of speech in which a word or phrase is used in a non-basic sense, this non-basic sense suggesting a likeness or analogy with another more basic sense of the same word or phrase." It can be observed that these definitions do not state explicitly whether one component of metaphor must be hidden or not. Such a kind of metaphor is so subtle to identify.

In Arabic, the noun, Isti Sarah derives from the verb Ista Sara, meaning to ask to casually borrow something from someone or somewhere. By implication, the process of borrowing involves three things, one being the borrowed object, another the object borrowed from, and third the object borrowed to. For instance, John borrowed (Ista Sara) the book from the library. The book, the borrowed thing, is carried over outside the library. The library is the original place from which the book is borrowed. John is the borrowee, who temporarily has the right to use what is borrowed. The sentence (John borrowed the book from the library) means that he took the book outside the library in order to use it. What is borrowed is transferred or carried over from the library the (source) domain to the borrower the (target) domain. Temporarily, the target domain is associated with the source domain by means of the book, acting as the unifying unit between the two domains. In light of this meaning of the word, Ista Sara can be defined as linguistic borrowing of a lexical unit as argued by Arab theorists. Notable among them is Ibn Al-Mutazz (1935), who defines Isti Sarah as the act of borrowing a word and associating it with a strange thing. Following Aristotle, Tha'lab (Hashim, 1994) also argues that Isti Farah is giving an object the name of another. According to Al-Jurjani (Leezenberg, 2001, p. 47), Isti Sarah is a word "applied to something other than was originally meant by it, and temporarily carried over onto something else, so that it appears there, so to speak, as if it were borrowed." This kind of borrowing aims at temporarily establishing similitude between what is borrowed from and what is borrowed to. In defining Isti Yarah, Ibn Qutaiba (Cohen, 2003, p. 56) suggests, "The Arabs "borrow" (tasta Siru) one word and then put it in the place of another word, provided the thing named by it (i.e., the first word) is related casually to the other one, or adjacent to it or similar [to it]."

It is imperative to suggest that this process of linguistic borrowing involves the transference of a lexical unit from one semantic field to another. Like Western theorists, Arab rhetoricians, such as Abu Ubaydah (1905), define metaphor as transferring a word from its original linguistic context to a new context not originally assigned to it. Consider the following example. The verb, "write," follows an animate subject, particularly a human being. You can say "The student writes his name," but according to the semantic norms, you cannot say "The mountain writes his name." The original context, in which this verb should be used, is that someone writes something. Otherwise, as the second example shows, the sense and features of someone who writes are semantically transferred to the mountain which logically cannot write. In this way, the mountain becomes like the student. That is, the mountain is identified with the student. Cohen (2003: 56) says: "Arab theorists observed that Isti Farah can always be traced to an underlying simile: the term X 
can be borrowed to refer to $\mathrm{Y}$ only if "X is like $\mathrm{Y}$ " in some way." However, it is noticeable that what Cohen (perhaps unintentionally) ignores is the obligatory textual absence of either $\mathrm{X}$ or $\mathrm{Y}$ as the most fundamental feature of metaphor in Arabic. It is in this apparent way that metaphor is different from simile, which involves the obligatory textual presence of both X and Y according to Al-Khafaji (1982) and Al-Jarjani (2006). After surveying how Western and Arab theorists define metaphor, it is not surprising to observe that metaphor, to a large extent, is viewed in a similar way apart from its cross-culturally controversial difference from simile.

\subsection{Types of Metaphor}

It can be argued that undeniably theoretical preoccupation with metaphor classification, presumably supposed to making metaphor translation as easy as falling off a log, unfortunately makes translation demanding if not impossible. That being the case, Dagut (1976), Van den Broeck (1981), and Newmark (1988) - each one of them confusingly categorizes metaphor in his own way. To begin with, Dagut (1976) suggests the following three categories of metaphors: (a) ephemeral metaphors of literature and journalism, (b) semantically embalmed metaphors of literature, and (c) metaphors taken up and used by many other speakers. In the same vein, Van den Broeck (1981) categorizes metaphor according to its form into three types: (a) Lexicalized metaphors, (b) Conventional metaphors, and (c) Private metaphors, which are created by poets. Similarly, Newmark (1988) categorizes metaphor into the following six types: (a) Dead metaphor, (b) Cliché metaphor, (c) Stock or standard metaphor, (d) Adapted metaphor, (e) Recent metaphor, and (f) Original metaphor.

Unlike Dagut (1976), Van den Broeck (1981) and Newmark (1988), Lakoff and Johnson (2003) coin the concept of conceptual metaphor and highlight its universality. In particular, they classify metaphor into (a) Orientational metaphor, which is related to spatial organization as in (up/down, front/back, on/off, near/far etc.); (b) Ontological metaphor, which associates activities, emotions, and ideas with entities and substances; and (c) Structural metaphor, built on the other two types, and allows structuring one concept in terms of another as in argument is war.

Apart from the above-mentioned categories, in English there are some linguistic classifications based on the absence and presence of the lexical units of metaphor. Direct metaphor, for instance, specifies both the tenor and the vehicle as in "John is a lion." If either the tenor or the vehicle is not specified, it is called implied metaphor. If the vehicle is specified, it is called implicit metaphor. Submerged metaphor does not specify the vehicle, but it retains one of its indicators, while the tenor is suspended from the text.

Like Western theorists, Arab theorists differ also in their classifications of metaphor. Abdul-Raof (2006) summarizes the main types of metaphor as suggested by Arabic rhetoricians. The types include explicit, implicit, proverbial, enhanced, naked, and absolute metaphors. Al-Jurjani (Leezenberg, 2001, pp. 48-50) suggests two types of metaphor: the first is non-expressive metaphor, which relies on synonyms of two words as in using "claws" in lieu of "hands." The second is expressive metaphor, classified as that with and that without a "referential substrate" as in "I saw a lion."

That cross-culturally lexical turmoil in classifying metaphor calls for a new metaphor classification, drawing on Richards's terminology (1936):

1- Vehicle-oriented metaphor: it requires the textual presence of the vehicle in the metaphorical expression as in "Your eyes strike arrows."

2- Tenor-oriented metaphor: it requires the textual presence of the tenor in the metaphorical expression. The vehicle is hidden, but a relevant indicator to it is explicitly stated. This indicator semantically does not go with the vehicle (i.e. it deviates from the norm). For instance, when one says: "The flowers dance," he likens flowers to girls. He deletes girls and retains an indicator (dance)

3- Tenor-vehicle-integrated metaphor: it requires the textual presence of both the tenor and vehicle. Both are explicitly stated in the metaphorical expression as in "John is a lion." It is important to iterate that this type of metaphor is considered an expressive simile in Arabic rhetoric.

4- Implied metaphor: it includes either vehicle-oriented metaphor or tenor-oriented metaphor

\subsection{Pitfalls of Well-known Models}

Metaphor translation theorists, including Van den Broeck (1981), Newmark (1988), Larson (1998), and Morneau (Fadaee, 2011, p. 176) iterate almost the same procedures for translating metaphor. Their procedures involve these three stages: (1) keeping the same metaphor, (2) substituting metaphor with another equivalent metaphor or simile, and (3) demetaphorization. Common to all these procedures is a huge gap in translating implied metaphor and in suggesting procedures for retaining the same metaphor with the same connotations. Apparently, only the first two operate effectively in translating poetical metaphors. To begin with, Van den Broeck (1981) suggests the following three procedures: (1) Translation 'sensu stricto' by which both the tenor and the vehicle in the source language are transferred into the target language; (2) Substitution in which the source language vehicle is replaced by a different one in the target language, but the tenor is more or less kept; and (3) Paraphrase where a metaphor is rendered by a non-metaphorical expression in the target language. Van den Broeck iterates almost the same procedures. However, unlike Newmark, Van den Broeck refers to the tenor and vehicle of metaphor. In the process, Van den Broeck's procedure (1) can be reworded as changing metaphor into simile. This means that keeping the same metaphor is invalid because one of the elements must be hidden. As for procedure (2), replacing the source language vehicle with target language vehicle is not safe because the target language vehicle might not exactly have the same connotations of the source language vehicle. As argued above, paraphrasing demetaphorizes the metaphor. 
Like Van den Broeck (1981), Larson (1998) suggests the following steps: (1) keeping the same metaphor if the receptor language permits; (2) translating metaphor as simile; (3) substituting metaphor with metaphor of the receptor language which has the same meaning; (4) keeping the same metaphor along with explaining its meaning by adding the topic or point of similarity; and finally (5) translating the meaning of the metaphor without keeping the metaphorical imagery.

In following Van den Broeck (1981), both Newmark (1988) and Larson (1998) suggest the following eight procedures for translating metaphor:

(1) Reproducing the same image in the target language.

(2) Translating the same metaphor combined with sense.

(3) Translating metaphor by simile.

(4) Translating metaphor by simile plus sense.

(5) Replacing the image in the source language with a standard target language image.

(6) Modification of metaphor

(7) Converting metaphor to sense.

(8) Deleting.

Out of those eight procedures, which demetaphorize the poetical metaphor, only (1) and (5) retain almost the metaphorical effect by means of translating metaphor into metaphor. Keeping the same image in the target language is debatable. The following questions arise naturally: Does keeping the same image convey the same connotations in the target language? Does retaining the same image in the target language involve keeping the same metaphorical expressions? If not, does the metaphorical effect differ? Newmark (1988) does not even consider those questions or suggest procedures for keeping the same metaphor. The other procedures deprive poetry of its poetical metaphor. In so doing, translating poetical metaphor into simile or even sense negatively affects the quality of translating poetry because metaphor (it can be argued) is the soul of poetry, and, thus, such a translation deprives metaphor of its allure. More importantly, procedure (6) needs further investigation. Newmark (1988) does not explain further how to translate the most appropriate sense if the metaphor has more than one. An in-depth analysis of the three translations of the poem, as will be shown below, reveals that the sense is divided into three subcategories: exact sense, partial sense, and wrong sense. The point here is that some of Newmark's procedures need modification, focusing on how to retain the same image and how to convert the metaphor into simile or even into sense.

In the same vein, Morneau (Fadaee, 2011, p. 176) states five techniques, similar to Newmark's: (1) Translating metaphor exactly, word-for-word; (2) Re-phrasing metaphor as simile; (3) Translating metaphor into an equivalent metaphor in the target language; (4) Translating metaphor using literal language; and (5) Using metaphor, but providing all the necessary referents so that any listener will understand it. It can be suggested that Larson and Morneau who have not innovated any new procedures, but have iterated Newmark's model without modifying or even building on it.

On the whole, the procedures, explained above, are similar not only in their iteration but also in their inability to propose any new procedures for translating metaphor into the same metaphor or translating implied metaphor into implied metaphor. They also leave out of account the differences that emerge between metaphor in English and metaphor in other languages such as Arabic. What is considered metaphor in English might not be metaphor in Arabic as argued above.

\subsection{Towards a New Model for Implied Metaphor Translation}

The translators' failure in translating implied metaphor in "Muallaqa of Imru Al-Qais" is in accord with the belief that metaphor in poetry is highly untranslatable as argued by Van den Broeck (1981). Along with this controversial argument, the translators' failure, attributed to their misunderstanding of the poem and unawareness of the nature of Arabic rhetoric, intrigues the researcher to propose the following steps that help translating implied metaphor into implied metaphor - a proposal that no previous study has tackled so far:

1- Underline the linguistic metaphorical expression(s) (i.e. the semantically deviated expression) and name it subordinate metaphor.

2- Identify the directly stated linguistic component of subordinate metaphor. You have to decide whether it is the tenor or the vehicle. If it is the tenor, this type of metaphor is called tenor-oriented metaphor. If it is the vehicle, this metaphor is called vehicle-oriented metaphor.

3- Identify the other implicit component of subordinate metaphor, which must be inferred from the context.

4- Transform that metaphor into tenor-vehicle-integrated metaphor as follows: (Tenor is Vehicle).

5- Infer what the directly stated linguistic component of subordinate metaphor belongs to. For instance, if this linguistic component is a leaf, it belongs to a tree.

6- Infer what the implied linguistic component of subordinate metaphor belongs to. For instance, if this linguistic component is an eye, it belongs to the face.

7- Consider those components to which the components of subordinate belong to as parts of the main metaphor, which might be classified super-ordinate metaphor.

8- Remember that the tenor of subordinate metaphor is subordinated to the tenor of super-ordinate metaphor, and the vehicle of subordinate metaphor is also subordinated to the vehicle of super-ordinate metaphor.

9- Transfer the super-ordinate metaphor into tenor-vehicle-integrated metaphor as follows: (Tenor is Vehicle). 
10- Realizing that subordinate metaphor derives from super-ordinate metaphor, assign the tenor and vehicle of super-ordinate metaphor $(\mathrm{T})$ and $(\mathrm{V})$, respectively and those of subordinate metaphor (t1) and (v1), respectively.

11- Incorporate only (v1) and (T) in your translation. Do not translate (t1).

\section{Conclusion}

By way of concluding, it can be said that the sincerity of implied metaphor translation is estimated by the strategy employed by the translator. It is translating the explicit linguistic component (in particular, keeping the same metaphor and using personification) that makes translation more reliable. Unfortunately, out of the fourteen examples, Johnson and Arberry translated four and six examples respectively in which both used personification and kept the same metaphor. However, Jones translated only one example out of twelve in which he used only personification. Apparently, Jones' translation was the poorest, whereas Johnson's and Arberry's translations were quite equally more sincere than Jones'. That similarity between Johnson and Arberry might imply that the latter relied heavily on the former. However, none of the three translators succeeded in translating most of the examples properly - a failure that might be attributed to the discrepancies of metaphor classification in English and Arabic and to their misunderstanding of the source implied metaphor along with their unawareness of the most appropriate strategy they needed in order to sort out such a dilemma. Such a failure intrigues the researcher to propose a new cross-linguistic classification of metaphor -- a classification that might better belittle the discrepancies of other classifications -- and a new model for translating implied metaphor into implied metaphor properly.

\section{References}

Abdul-Raof, H. (2006). Arabic Rhetoric: A Pragmatic Analysis. New York: Routledge.

Abu Libdeh, A. (2011). Metaphor in Arabic Rhetoric: A Call for Innovation. Jordan Journal of Applied Sciences,13 (1), 227-242.

Abu Ubaydah, M. T. (1905). In Bevan, A. A. (ed.) The Naka'id of Jarir and al-Farazdak, Volume 1. Leiden: Brill.

Alhasan, W. Z. (2012). A Stylistic Analysis of Literary Translations: The Golden Odes of Pagan Arabia by Wilfrid Scawen Blunt and Lady Anne Blunt. (Unpublished MA Thesis). Mutah University, Kerak.

Al-Jarjani, A. (2006). Al-Wasatah bayn al-Mutannabi wa Khusumihi, Ibrahim, M. \& al- Bajawi, A. (eds.). Beirut: AlMaktabah Al-Asriyah.

Al-Jurjani, A. (n.d.) Dalail Alijaz, Shakir, M (ed.). Cairo: al-Khanji Library.

Al-Khafaji, I. (1982). Sirr Al-fasaha. Beirut: Dar Al-Kutub Al-Ilmiyah.

Arberry, J. A. (1957). The Seven Odes. London: George Allen \& Unwin Ltd.

Cohen, M. Z. (2003). Three Approaches to Biblical Metaphor: From Abraham Ibn Ezra and Maimonides to David Kimhi. Leiden: Brill.

Dagut, M. (1976). Can "Metaphor" Be Translated? Babel, 22(1), 21-33.

Decter, J. P. (2007). Iberian Jewish Literature between Al-Andalus and Christian Europe. Bloomington: Indiana University Press.

Deignan, A. (2005). Metaphor and Corpus Linguistics. Amsterdam: John Benjamins Publishing Co.

Dickins, J., Harvey S. \& Higgins, I. (2002). Thinking Arabic Translation: A Course in Translation Method: Arabic to English. London: Routledge.

Dickins, J. (2005). Two Models for Metaphor Translation. Target, 17(2), 227-273.

Fadaee, E. (2011). Translation Techniques of Figures of Speech: A Case Study of George Orwell's 1984 and Animal Farm. Journal of English and Literature, 2(8), 174-181.

Hashim, Z. Y. (1994). Al-IstiS arah Fi A'amal Abd al-Qahir al-Jurjani [Implied Metaphor in the Works of Abd alQahir al-Jurjani]. Mecca: University of Um al-Qura. Unpublished MA Thesis.

Ibn al-Mutazz, A. (1935). Kitab al-Badi', Kratchkovsky, I. (ed.). London: Messers Luzac and Co.

Johnson, F. (1893). The Seven Poems Suspended in the Temple of Mecca. Bombay: Education's Society's Steam Press.

Jones, W. (1807). Works of Sir William Jones. (Vol. 10). London: John Stockdale, Piccadilly, John Walker, PaternosterRow.

Lakoff, G. \& Johnson, M. (2003). Metaphors We Live By. Chicago: University of Chicago Press.

Larson, M. L. (1998). Meaning-Based Translation: A Guide to Cross-Language Equivalence. Lanham:University Press of America, Inc.

Leezenberg, M. (2001). Contexts of Metaphor. Oxford: Elsevier Science Ltd. Metaphor. Online Etymology Dictionary. Retrieved From http://www.etymonline.com/index.php?allowed_in_frame=0\&search=metaphor\&searchmode=none.

Newmark, P. (1988). A Textbook of Translation. New York: Prentice-Hall International.

Richards, I. A. (1936). The Philosophy of Rhetoric. New York and London: Oxford University Press. 
Rihani, Z. (2002). Metaphor, Image, and Music in a Line by Nizar Qabbani. Translation Review, 62, 54-59.

Rura, L. (2010). Analysis of Translated Tropes: Metaphors, Similes \& Analogies in a Case Study of the English \& Dutch Translations of the Russian Poet Alexander Galich. Proceedings of the Conference Found in Translation. Kuala Lumpur: Ghent University College.

Simawe, S. A. (2001). Modernism \& Metaphor in Contemporary Arabic Poetry. World Literature Today,75(2), $275-84$. Stamvobsky, Ph. (1988). The Depictive Image: Metaphor and Literary Experience. Massachusetts: Massachusetts University Press.

Van den Broeck, R. (1981). The Limits of Translatability Exemplified by Metaphor Translation. Poetics Today, 2(4), 73-87.

Vivian, P. (1900). A Dictionary of Literary Terms. London: George Routledge \& Son.

Youssefi, K. (2009). An Analysis of the Translation of Metaphors in Hafiz's Selected Poems. Unpublished PhD Dissertation. University of Sains Malaysia.

Zohdi, M., \& Saeedi, A. A. (2011). Translating Metaphor and Simile from Persian to English: A Case Study of Khayyam's Quatrains. Theory and Practice in Language Studies, 1(9), 1122-1138.

\section{Acknowledgments}

I would like to thank Wasan Alhasan for reading and commenting on the prepublication draft of this paper and for transliterating the verses.

\section{Appendices}

Appendix (1) Classification and Components of Source Metaphor

\begin{tabular}{|c|c|c|c|c|c|}
\hline No. & Source Text & Transliterated Text & Type of Metaphor & Tenor & Vehicle \\
\hline 1 & ولا تبعديني من جناك & $\begin{array}{l}\text { wa la tubSideeni min } \\
\text { janakil-mu\{allali }\end{array}$ & vehicle-oriented & kisses & $\begin{array}{l}\text { Janakil, } \\
\text { meaning your } \\
\text { fruits }\end{array}$ \\
\hline 2 & فسلي ثيابي من ثيابك تتسل & $\begin{array}{l}\text { fa sulli } \theta i j \text { abi min } \\
\text { eijabiki tansali }\end{array}$ & vehicle-oriented & my heart & $\begin{array}{l}\text { eijabi, } \\
\text { meaning } \\
\text { my garments }\end{array}$ \\
\hline 3 & الا لتضربي بسهميك & $\begin{array}{l}\text { illa litaDribi } \\
\text { bisahmaiki }\end{array}$ & vehicle-oriented & tears & $\begin{array}{l}\text { sahmaiki, } \\
\text { meaning } \\
\text { your two } \\
\text { arrows }\end{array}$ \\
\hline 4 & وبيضة خدر & wa baiDati xidrin & vehicle-oriented & beloved & $\begin{array}{l}\text { baiDati, } \\
\text { meaning } \\
\text { egg }\end{array}$ \\
\hline 5 & بناظرة من وحش وجرة & $\begin{array}{l}\text { bi naĐiratin min } \\
\text { wah } \int I \text { wad3rata } \\
\text { muTfili }\end{array}$ & vehicle-oriented & Beloved's eyes & $\begin{array}{l}\text { naĐiratin, } \\
\text { meaning } \\
\text { roe's eyes }\end{array}$ \\
\hline 6 & فقلت له لما تمطى بصلبه & $\begin{array}{l}\text { fa quitu lahu lamma } \\
\text { tamaTTa biSulbihi }\end{array}$ & tenor-oriented & $\begin{array}{l}\text { Sulbihi, } \\
\text { meaning } \\
\text { camel's loins }\end{array}$ & midnight \\
\hline 7 & و أردف أعجاز آ & wa ardafa a\{djazan & tenor-oriented & $\begin{array}{l}\text { ådjazan, } \\
\text { meaning } \\
\text { camel's } \\
\text { buttocks }\end{array}$ & dawn \\
\hline 8 & وناء بكلكل & wa na?a bikalkali & tenor-oriented & $\begin{array}{l}\text { Kalkali, } \\
\text { meaning } \\
\text { Camel's breast }\end{array}$ & evening \\
\hline 9 & وقربة أقو ام جعلت عصلى عنى عنى & $\begin{array}{l}\text { wa qirbati aqwamin } \\
\text { d3aSaltu SiSamaha } \\
\text { Sala kahilin minni }\end{array}$ & vehicle-oriented & people's rights & $\begin{array}{l}\text { qirbati, } \\
\text { meaning }\end{array}$ \\
\hline
\end{tabular}




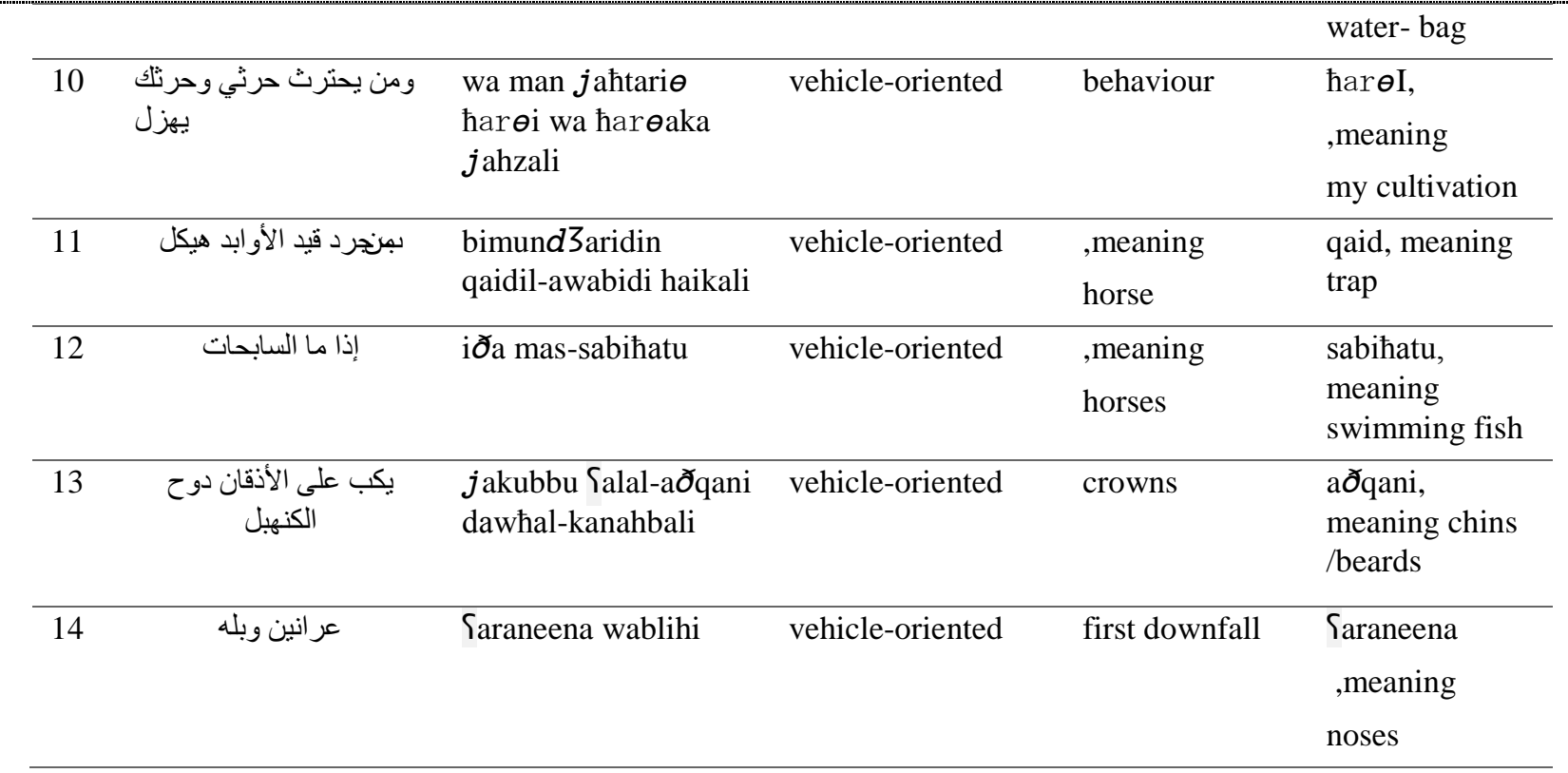

Appendix (2) Jones's, Johnson's and Arberry's Translations

\begin{tabular}{|c|c|c|c|c|}
\hline No. & $\begin{array}{c}\text { Source and } \\
\text { Transliterated Verses }\end{array}$ & Jones's translation & Johnson's translation & Arberry's translation \\
\hline 1. & 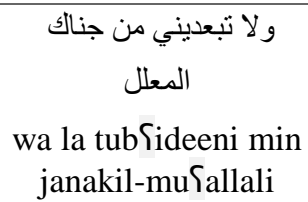 & $\begin{array}{l}\text { nor withhold from me the fruits of } \\
\text { thy love, which again and again } \\
\text { may be tasted with rapture }\end{array}$ & $\begin{array}{l}\text { and do not repel me from your } \\
\text { repeatedly tasted fruit }\end{array}$ & $\begin{array}{c}\text { and oh, don't drive me } \\
\text { away from your refreshing } \\
\text { fruit }\end{array}$ \\
\hline 2. & $\begin{array}{c}\text { فسلي ثبابي من ثيابك تتسل } \\
\text { fa sulli өijabi min } \\
\text { өijabiki tansali }\end{array}$ & $\begin{array}{l}\text { rend at once the mantle of my } \\
\text { heart, that it may be detached } \\
\text { from thy love }\end{array}$ & $\begin{array}{l}\text { then put away my heart from } \\
\text { your heart, and it will be put } \\
\text { away }\end{array}$ & $\begin{array}{l}\text { just draw off my garments } \\
\text { from yours, and they will } \\
\text { slip away }\end{array}$ \\
\hline 3. & $\begin{array}{l}\text { الا لتضربي بسهميك } \\
\text { illa litaDribi } \\
\text { bisahmaiki }\end{array}$ & $\begin{array}{c}\text { yet thy tears flow merely to } \\
\text { wound my heart with the shafts of } \\
\text { thine eyes }\end{array}$ & $\begin{array}{c}\text { your two eyes did not flow with } \\
\text { tears, except to strike me with } \\
\text { your two arrows in my broken } \\
\text { heart }\end{array}$ & $\begin{array}{l}\text { Your eyes only shed those } \\
\text { tears so as to strike and } \\
\text { pierce with those two shafts } \\
\text { of theirs }\end{array}$ \\
\hline 4. & وبيضة خدر & with many a spotless virgin & many a fair one & Many's the fair veiled lady \\
\hline
\end{tabular}

wa baiDati xidrin

\begin{tabular}{|c|c|c|c|c|}
\hline 5. & $\begin{array}{c}\text { بناظرة من وحش وجرة } \\
\text { bi naĐiratin min } \\
\text { waћSI wad3rata } \\
\text { muTfili }\end{array}$ & $\begin{array}{l}\text { she gave a timid glance with } \\
\text { languishing eyes, like those of a } \\
\text { roe in the groves of Wegera } \\
\text { looking tenderly at her young }\end{array}$ & $\begin{array}{c}\text { She ... is prohibiting me from } \\
\text { caressing her with a glancing } \\
\text { eye, like that } \\
\text { of a wild animal, with young, in } \\
\text { the desert of Wajrah }\end{array}$ & $\begin{array}{l}\text { She turns away, to show a } \\
\text { soft cheek, and wards me } \\
\text { off, with the glance of a } \\
\text { wild deer of Wajra, a shy- } \\
\text { gazelle with its fawn }\end{array}$ \\
\hline 6. & $\begin{array}{l}\text { فقلت له لما تمطى بصلبه } \\
\text { fa qultu lahu lamma } \\
\text { tamaTTa biSulbihi }\end{array}$ & $\begin{array}{l}\text { when she seemed to extend her } \\
\text { sides }\end{array}$ & $\begin{array}{l}\text { Then I said to him, (i. e., the } \\
\text { night), when he stretched his } \\
\text { loins }\end{array}$ & $\begin{array}{l}\text { and I said to the night, } \\
\text { when it stretched its lazy } \\
\text { lions }\end{array}$ \\
\hline
\end{tabular}

\begin{tabular}{|c|c|c|}
\hline $\begin{array}{c}\text { وأردف أعجاز } \\
\text { wa ardafa aSd3azan }\end{array}$ & to drag on her unwieldy length & $\begin{array}{l}\text { and followed it with his } \\
\text { buttocks }\end{array}$ \\
\hline
\end{tabular}

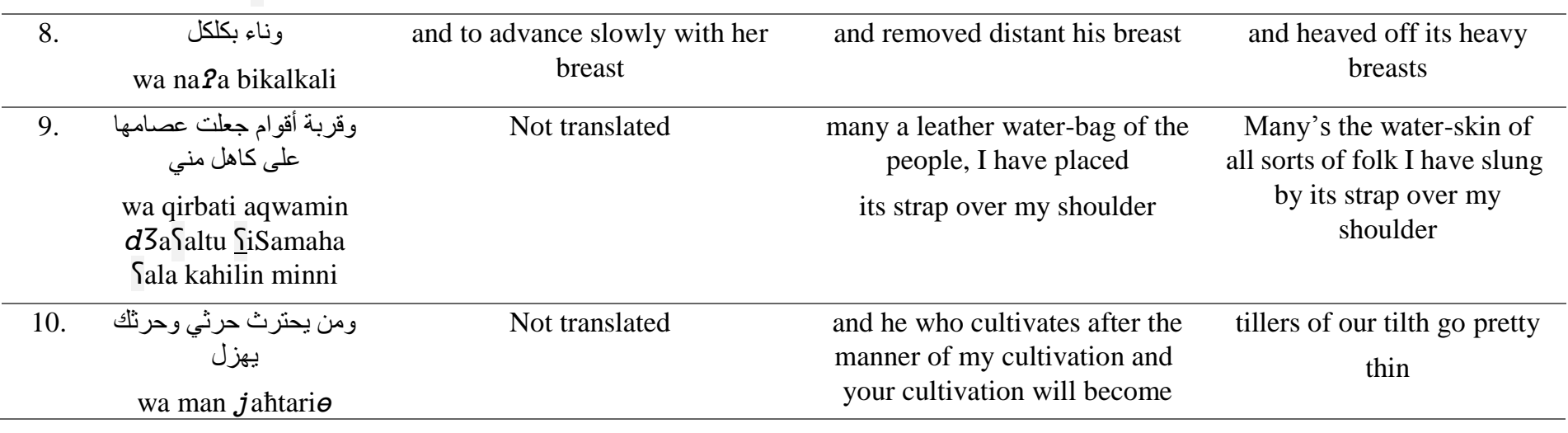


harei wa hareaka

thin

jahzali

11. بمنجرد قيد الأوابد هيكل a hunter with smooth short hair, of bimund 3aridin qaidil-awabidi haikali a full height, and so fleet as to make captive the beasts of the forest on a horse well-bred, long bodied, outstripping the wild beasts in his gallop my horse short-haired, outstripping the wild game, huge- bodied

12

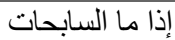

Other horses that swim

When the swift horses

When the mares

iða mas-sabiћatu

13. يكب على الأذقان دوح

$$
\text { الكنهبل الأقان }
$$

till the rushing torrent lays prostrate the groves of canahbel-

jakubbu Salalaðqani dawhaltrees kanahbali

14. عر انين وبله in the heights of the flood

Saraneena wablihi

The storm commenced pouring out its waters over Kathaifah overturning upon their faces the big trees called kanahbul floundering wearily

the cloud started loosing its torrent about Kutaifa

turning upon their beards the boles of the tall kanahbals at the first downfall of its rain

when the first onrush of its deluge came

Appendix (3) Arabic Letters and Their Transliterated Symbols

\begin{tabular}{|c|c|c|}
\hline No. & Letter & IPA Symbol \\
\hline 1. & $\varepsilon$ & 个 \\
\hline 2. & ي & $j$ \\
\hline 3. & ض ض & $\mathrm{D}$ \\
\hline 4. & ص & $\mathrm{S}$ \\
\hline 5. & ظ & $Đ$ \\
\hline 6. & b & $\mathrm{T}$ \\
\hline 7. & $\dot{\tau}$ & $\mathrm{x}$ \\
\hline 8. & $\tau$ & $\hbar$ \\
\hline 9. & ج & $d 3$ \\
\hline 10. & ش & $\int$ \\
\hline 11. & ق & $q$ \\
\hline 12. & 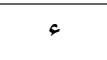 & $?$ \\
\hline 13. & $\dot{j}$ & $\partial$ \\
\hline
\end{tabular}

\section{Notes}

${ }^{\mathrm{i}}$ See Appendix 1.

ii See Appendices 2 and 3. 